NBER WORKING PAPER SERIES

\title{
IN-STATE VERSUS OUT-OF-STATE STUDENTS: \\ THE DIVERGENCE OF INTEREST BETWEEN PUBLIC UNIVERSITIES AND STATE GOVERNMENTS
}

\author{
Jeffrey A. Groen \\ Michelle J. White \\ Working Paper 9603 \\ http://www.nber.org/papers/w9603 \\ NATIONAL BUREAU OF ECONOMIC RESEARCH \\ 1050 Massachusetts Avenue \\ Cambridge, MA 02138 \\ April 2003
}

We are grateful to John Bound, Charles Brown, Paul Courant, Julie Cullen, Caroline Hoxby, Jim Poterba, Rohini Somanathan, and the referees for very helpful comments. Previous versions of this paper were presented at University of Michigan, the NBER Higher Education Workshop, and Cornell University. The views expressed herein are those of the authors and not necessarily those of the National Bureau of Economic Research.

(C2003 by Jeffrey A. Groen and Michelle J. White. All rights reserved. Short sections of text not to exceed two paragraphs, may be quoted without explicit permission provided that full credit including Cnotice, is given to the source. 
In-State versus Out-of-State Students:

The Divergence of Interest between Public Universities and State Governments

Jeffrey A. Groen and Michelle J. White

NBER Working Paper No. 9603

April 2003

JEL No. I2, I29

\begin{abstract}
This paper examines the divergence of interest between universities and state governments concerning standards for admitting in-state versus out-of-state students. States have an interest in using universities to attract and retain high ability individuals because they pay higher taxes and contribute more to economic development. In contrast, universities have an interest in their graduates being successful, but little interest in where students come from or where they go after graduation. We develop and test a model that illustrates the divergence of interest between universities and their states. We find that public universities set lower minimum admissions standards for in-state than out-of-state applicants, presumably following their states' preferences, while private universities on average treat both groups equally. However we find that states in fact gain financially when public universities admit additional out-of-state students. This is because attending a public university in a particular state increases marginal students' probability of locating in the state after graduation by the same amount regardless of whether students are from in-state or out-of-state. And because marginal out-of-state students earn more, their expected future state tax payments are higher.
\end{abstract}

We also estimate states' financial gain when public and private universities admit additional in-state versus out-of-state students who have middle and high ability levels. Surprisingly, we find that high ability students tend to be at least as strongly influenced in their adult location choices by where they attend university than are middle and low ability students. Since high ability students also earn more, this suggests that states gain financially when their universities attract high ability students, regardless of whether the students are from in-state or out-of-state or the universities are public or private. Our results suggest a rationale for public support of flagship public universities that can attract high-ability students.

Jeffrey A. Groen

Cornell University

Ithaca, New York 14853-3901

jg277@cornell.edu
Michelle J. White

Department of Economics

University of California, San Diego

La Jolla, CA 92093-0508

and NBER

mwhite@ucsd.edu 


\title{
In-State versus Out-of-State Students: The Divergence of Interest between Public Universities and State Governments ${ }^{1}$
}

\author{
Jeffrey A. Groen and Michelle J. White
}

States have an interest in using their public universities as tools to encourage economic development. University study increases students' human capital. Graduates with high levels of human capital contribute to their local economies by starting their own new businesses, attracting other businesses to the area, and raising wages generally. Attending a university in a particular state increases graduates' likelihood of locating in the state as adults because they develop local connections. If attending university has a different effect on in-state versus out-of-state students' probabilities of locating in that state, then states have an interest in favoring the particular group whose location decisions are most sensitive at the margin.

However universities' interests differ from those of their states. Both public and private universities have an interest in attracting high ability students, in maximizing revenue from tuition and donations, and/or in having graduates who are rich and famous, but they have little interest in where their students come from or where they go after graduation. Public universities in particular often have a financial incentive to favor out-of-state over in-state students, because out-of-state students pay higher tuition and universities may be able to keep the additional revenue for their own purposes. Private universities have no particular interest in encouraging economic development in their home regions, since economic development raises wages and land prices. These factors suggest that there is a divergence of interest between public and private universities and their state governments. Universities do not necessarily have an incentive to act in the best interests of their states.

In this paper, we explore the divergence of interest between public and private universities and their states. We focus on standards for admission of in-state versus out-of-state students and on whether universities act in their states' interest in setting these standards. After a brief literature review, section 2 develops several behavioral rules that represent states' interest and universities' interest in admitting in-state versus out-of-state students. These rules illustrate the divergence of interest between universities and their state governments. Section 3 tests the models using data

\footnotetext{
${ }^{1}$ We are grateful to John Bound, Charles Brown, Paul Courant, Julie Cullen, Caroline Hoxby, Jim Poterba, Rohini Somanathan, and the referees for very helpful comments. Previous versions of this paper were presented at University of Michigan, the NBER Higher Education Workshop, and Cornell University.
} 
from College and Beyond for public and private universities. We find that public universities set lower minimum admissions standards for in-state than out-of-state applicants, while private universities treat both groups equally. However, correcting for selection bias, we find that the location decisions of marginal in-state and out-of-state students are equally affected by attending a public university. Because marginal out-of-state students have higher future earnings than marginal in-state students, this means that states lose rather than gain financially when public universities favor in-state applicants for admission. Finally we examine whether states would benefit if public universities imposed maximum as well as minimum standards for admission. ${ }^{2}$

\section{Literature Review}

Goldin and Katz's (1998) study of the growth of public higher education from 1890 to 1940 supports the idea that state governments historically viewed public universities as tools for encouraging economic development. During this period, manufacturing, mining, and agriculture were all becoming more specialized and science-based. States that had substantial economic activity in particular fields often established specialized public universities to train workers in these fields and conduct research to advance the fields. Examples include tobacco farming in North Carolina, dairy farming in Wisconsin, mining in Colorado, and oil exploration in Texas. Since public universities provided training in fields that their states specialized in, graduates tended to remain in the state. This allowed states to capture the benefits of their investments.

College graduates create external benefits for other workers in the labor markets where they locate as adults, regardless of whether they work in the specific fields that the state's economy specializes in. Moretti (2002) finds that wages of both high school and college graduates are positively correlated with the share of college graduates in the local labor market. Also, college graduates earn more than other workers and therefore pay higher state taxes. College graduates are also more likely than other workers to start new businesses, which generate jobs for other workers and raise demand for labor (Fan and White, 2002).

Since the period studied by Goldin and Katz, markets for college education and collegeeducated labor have become more spatially integrated. Hoxby (1997) argues that U.S. universities have been transformed from local autarkies into competitors, since students who previously attended universities close to home are now likely to attend universities that are further away. This

\footnotetext{
${ }^{2}$ For ease of exposition, we use the terms "university," "college," and "institution" interchangeably.
} 
means that universities are increasingly forced to compete for students on regional or national markets. As part of the same trend, demand for enrollment by out-of-state students has increased at the top public universities (Mixon and Hsing, 1994).

The fact that college graduates from one state may locate in other states after graduation affects states' incentives to invest in higher education. Strathman (1993) and Quigley and Rubinfeld (1993) show empirically that states with more mobile populations spend less on public higher education. Presumably these states expect to attract educated migrants from other states and/or expect local students to move elsewhere, so that they have less incentive to provide public universities to educate the local population. There may be a rationale for Federal intervention to subsidize provision of public universities in states that have high migration rates .

\section{Theory}

We first examine public and private universities' interest in admitting in-state versus out-ofstate students and then turn to the state's interest. Our model focuses on selective universities because, among public universities, only those that are selective attract out-of-state applicants. Because the model is intended for empirical implementation, we intentionally keep it simple.

\subsection{The university's interest}

The "equal cutoff rule." Consider first the interest of public and private universities in admitting in-state versus out-of-state students. Suppose the ability level of an in-state student $i$ is denoted $s_{i}$ and the ability level of an out-of-state student $o$ is denoted $s_{o}$. The numbers of in-state and out-of-state students of ability level $s_{i}$ and $s_{o}$ who apply to the university and would attend if accepted are denoted $n_{i}\left(s_{i}\right)$ and $n_{o}\left(s_{o}\right)$ for in-state and out-of-state students, respectively.

Assume that universities select students by adopting minimum cutoff scores of $\bar{s}_{i}$ and $\bar{s}_{o}$ for in-state and out-of-state applicants, respectively. They reject all in-state applicants with $s_{i}<\bar{s}_{i}$ and accept all in-state applicants with $s_{i} \geq \bar{s}_{i}$, and similarly for out-of-state applicants. ${ }^{3}$ Universities

\footnotetext{
${ }^{3} n_{i}\left(s_{i}\right)$ equals the number of in-state applicants of ability level $s_{i}$ times the proportion of in-state applicants of ability level $s_{i}$ who would attend if accepted. The same applies to $n_{o}\left(s_{o}\right)$. The functions $n_{i}\left(s_{i}\right)$ and $n_{o}\left(s_{o}\right)$ are likely to differ because in-state applicants are more likely to attend university near their homes. We treat these functions as fixed because our dataset does not contain information on the full set of applicants to particular institutions.
} 
have binding capacity constraints (total class size) of $\bar{N}$. Universities' goal is to set the cutoff levels $\bar{s}_{i}$ and $\bar{s}_{o}$ so as to maximize students' average ability level:

$$
\left(\frac{1}{\bar{N}}\right)\left[\int_{\bar{s}_{i}}^{\infty} s_{i} n_{i}\left(s_{i}\right) d s_{i}+\int_{\bar{s}_{o}}^{\infty} s_{o} n_{o}\left(s_{o}\right) d s_{o}\right],
$$

subject to the capacity constraint:

$$
\bar{N}=\int_{\bar{s}_{i}}^{\infty} n_{i}\left(s_{i}\right) d s_{i}+\int_{\bar{s}_{o}}^{\infty} n_{o}\left(s_{o}\right) d s_{o} .
$$

The first order condition is:

$$
\bar{s}_{i}=\bar{s}_{o} .
$$

We refer to this result as the "equal cutoff rule" - it says that the cutoff levels for admission of instate and out-of-state students should be the same. It follows from the fact that universities are assumed to care only about the average ability of their students, not about where they come from. We test below whether public and private universities follow this rule. If private universities are found to set equal cutoffs for both types of students while public universities are found to set lower cutoffs for in-state students, then the result will provide support for the hypothesis that states require or pressure public universities to favor in-state over out-of-state applicants at the margin.

The "equal marginal revenue rule." Another formulation of universities' interest assumes that they maximize a hybrid of average student ability and total revenue. Suppose universities still admit students in declining order of ability until they reach the relevant cutoff, but they set the cutoff levels to maximize total revenue rather average student ability. Suppose $T_{i}$ and $T_{o}$ denote in-state and out-of-state tuition levels, respectively. Public universities always have higher tuition levels for out-of-state than in-state students, while private universities have a single tuition level for all students. Both types of universities may offer tuition discounts in the form of financial aid. Universities also collect revenue in the form of donations from graduates. Suppose $D_{i}\left(s_{i}\right)$ and $D_{o}\left(s_{o}\right)$ denote the expected present value of future donations from in-state and out-of-state students of ability levels $s_{i}$ and $s_{o}$, respectively. Future donations are assumed to depend on student ability, because ability is positively related to earnings. Assume now that universities set the cutoff levels $\bar{s}_{i}^{\prime}$ and $\bar{s}_{o}^{\prime}$ so as to maximize the sum of tuition plus donations from in-state and out-of-state students, or: 


$$
\frac{1}{\bar{N}}\left[\int_{\bar{s}_{i}^{\prime}}^{\infty}\left(D_{i}\left(s_{i}\right)+T_{i}\right) n_{i}\left(s_{i}\right) d s_{i}+\int_{\bar{s}^{\prime}{ }_{o}}^{\infty}\left(D_{o}\left(s_{o}\right)+T_{o}\right) n_{o}\left(s_{o}\right) d s_{o}\right],
$$

subject to the capacity constraint, eq. (2).

The first order condition is:

$$
D_{i}\left(\bar{s}_{i}^{\prime}\right)+T_{i}=D_{o}\left(\bar{s}_{o}^{\prime}\right)+T_{o} .
$$

This rule - the "equal marginal revenue rule" - says that universities set the cutoff levels such that they collect the same amount of revenue from marginal in-state and marginal out-of-state students.

The "equal marginal revenue rule" suggests reasons why both private and public universities might have an incentive to set different cutoff levels for in-state students (i.e., students who live nearby) versus for out-of-state (i.e., distant) students. One reason is that in-state students are more likely to locate close to the university as adults and this may cause them to donate more on average than out-of-state students having the same ability levels. Another reason is that universities have spatial monopoly power over in-state students, because some of them wish to attend college near their homes. Private universities can take advantage of this monopoly power by giving less financial aid to nearby students, but public universities probably cannot. (See Epple et al., 1999, for discussion.)

\subsection{The state's interest}

The "equal additional tax payments rule." Now consider the interests of an arbitrary state, which we refer to as state $X$. In line with the view that states view universities as tools of state economic development, we assume that state $X$ 's goal is to maximize the present value of future state tax revenues. Most states collect the bulk of their tax revenue from income and sales taxes. Because these taxes are roughly proportional to income, high ability individuals pay higher taxes because they earn more. (High income individuals tend to pay higher amounts of other state taxes, such as property taxes and business taxes, as well.) Therefore state $X$ has an interest both in retaining high ability in-state students and attracting high ability out-of-state students. Both in-state and out-of-state students are assumed to choose between attending college in state $X$ or in some other state. If students attend college in state $X$ rather than another state, we assume that their probability of locating in state $X$ as adults rises, regardless of where they are from. ${ }^{4}$

\footnotetext{
${ }^{4}$ For some in-state students, the best alternative to attending the most selective public university in state $X$ is to attend a less selective public university in state $X$, rather than a university in some other state. In this case students' probability
} 
Suppose $p_{k j}$ denotes students' probabilities of locating in state $X$ as adults. The subscript $k$ denotes home state and it equals $y$ if the student's home state is state $X$ and $n$ otherwise. The subscript $j$ denotes college state and it equals $y$ if the student attends college in state $X$ and $n$ otherwise. Thus $p_{y y}$ is the probability of students locating in their home states as adults if they attend college there, $p_{y n}$ is the probability of students locating in their home states as adults if they attend college out-of-state, and $\Delta p_{i}=p_{y y}-p_{y n}$ denotes the increase in the probability of in-state students locating in their home states if they attend college there rather than elsewhere. Similarly, $p_{n y}$ is the probability of out-of-state students locating in the state where they attend college as adults, $p_{n n}$ is the probability of students locating in a particular state as adults if they are neither from the state nor attend college there, and $\Delta p_{o}=p_{n y}-p_{n n}$ denotes the increase in the probability of out-of-state students locating in a particular state if they attend college there rather than elsewhere. We assume that all of these terms vary with students' ability levels. We further assume that both $\Delta p_{i}\left(s_{i}\right)$ and $\Delta p_{o}\left(s_{o}\right)$ are positive, but do not make any assumptions concerning their relative magnitude. (We estimate these terms in the next section.)

Suppose $\tau_{i}\left(s_{i}\right)$ and $\tau_{o}\left(s_{o}\right)$ denote the average present value of future state tax payments by instate graduates having ability level $s_{i}$ and out-of-state graduates having ability level $s_{o}$, respectively. The present value of future state tax revenues is assumed to increase with ability for both types of students, but the relationship is assumed to differ for in-state versus out-of-state students. The present value of future state tax revenues also varies across states because state tax rates differ. ${ }^{5}$

The state's goal is for the public university to set cutoff levels $\widetilde{s}_{i}$ and $\widetilde{s}_{o}$ so as to maximize the increase in expected future tax payments that results from in-state and out-of-state students, respectively, attending public university in state $X$ rather than elsewhere, or:

of locating in state $X$ as adults is likely to be unaffected by which public university in state $X$ they attend, so that according to our model - state $X$ does not benefit when they are admitted to the most selective public university. Because our dataset includes only public universities that are the most selective in their states, we ignore this possibility.

${ }^{5}$ The functions $\tau_{i}\left(s_{i}\right)$ and $\tau_{o}\left(s_{o}\right)$ may differ because the relationship between ability and future earnings/future state tax payments may differ for in-state versus out-of-state students. Note that students' future earnings could also depend on the type of university they attend, but we ignore this possibility. See Dale and Kreuger (2002) for discussion of whether graduates of selective universities earn more. 


$$
\left[\int_{\widetilde{s}_{i}}^{\infty} \Delta p_{i}\left(s_{i}\right) \tau_{i}\left(s_{i}\right) n_{i}\left(s_{i}\right) d s_{i}+\int_{\widetilde{s}_{o}}^{\infty} \Delta p_{o}\left(s_{o}\right) \tau_{o}\left(s_{o}\right) n_{o}\left(s_{o}\right) d s_{o}\right],
$$

subject to the same capacity constraint, eq. (2). The first order condition is:

$$
\Delta p_{o}\left(\tilde{s}_{o}\right) \tau_{o}\left(\tilde{s}_{o}\right)=\Delta p_{i}\left(\tilde{s}_{i}\right) \tau_{i}\left(\tilde{s}_{i}\right) .
$$

Eq. (7) says that the state wants the public university to set cutoff levels such that the additional expected future state tax revenue collected from the marginal student admitted is the same for instate versus out-of-state students. We call this the "equal additional tax payments rule." If the functions $\Delta p_{o}\left(s_{o}\right)$ and $\Delta p_{i}\left(s_{i}\right)$ are identical in the region of the cutoff levels and the functions $\tau_{i}\left(s_{i}\right)$ and $\tau_{o}\left(s_{o}\right)$ are also identical in the region of the cutoff levels, then the minimum cutoff levels $\widetilde{s}_{i}$ and $\widetilde{s}_{o}$ for in-state and out-of-state students should be the same. But if $\Delta p_{i}(s)>\Delta p_{o}(s)$ and/or $\tau_{i}\left(s_{i}\right)>\tau_{o}\left(s_{o}\right)$ in the region of the cutoff levels, then the state will tend to favor a lower cutoff level for in-state students, and vice versa.

The "tuition offset rule." States in fact receive revenue from students in two forms: tuition payments from current students and future state tax payments from graduates who locate in the state as adults. Therefore another formulation of the state's objective is for public universities to determine the cutoff levels for in-state versus out-of-state students by maximizing the sum of tuition revenues plus the increase in expected future tax revenues from both types of students, subject to the same capacity constraint. The first order condition implies that:

$$
T_{o}-T_{i}=\Delta p_{i}\left(\widetilde{s}_{i}^{\prime}\right) \tau_{i}\left(\widetilde{s}_{i}^{\prime}\right)-\Delta p_{o}\left(\widetilde{s}_{o}^{\prime}\right) \tau_{o}\left(\widetilde{s}_{o}^{\prime}\right) .
$$

This is the "tuition offset rule," which says that the extra tuition paid by marginal out-of-state students should just offset the extra future state tax payments paid by marginal in-state students admitted to the public university. If this condition holds, then public universities are acting according to the state's interest. But if the left hand side of condition (8) is less than the right hand side, then it would be in the state's interest for public universities to set a lower cutoff for in-state relative to out-of-state students, and vice versa. We test this rule below.

Maximum cutoffs. So far we have assumed that it is in states' interest for universities to admit students in declining order of ability and to set only minimum cutoff levels for admission of in-state and out-of-state students. However states may not have lexicographical preferences for higher over lower ability students and may in fact prefer that universities set multiple cutoffs for one or both 
groups of students. In particular, we investigate the possibility that states might have an interest in universities rejecting the highest ability applicants from in-state or out-of-state, because these students' location choices are unlikely to be affected by where they attend college. This possibility is of interest because state legislators often seem reluctant to support public universities at the expenditure levels required to attract high ability students.

Suppose $\tau_{o}\left(s_{o}\right)$ and $\tau_{i}\left(s_{i}\right)$ increase monotonically with ability (since earnings are positively related to ability), while $\Delta p_{i}\left(s_{i}\right)$ and/or $\Delta p_{o}\left(s_{o}\right)$ may not be monotonically related to ability. One possibility is that $\Delta p_{i}\left(s_{i}\right) \tau_{i}\left(s_{i}\right)$ and $\Delta p_{o}\left(s_{o}\right) \tau_{o}\left(s_{o}\right)$ have the shapes shown in figure 1. Assuming that the "equal additional tax payments rule" is followed, the minimum cutoff levels are set at $s_{i}{ }^{\min }$ and $s_{o}{ }^{m i n}$, where the two curves intersect on the left hand side of the figure. As $s_{i}$ increases, $\Delta p_{i}\left(s_{i}\right) \tau_{i}\left(s_{i}\right)$ increases monotonically, so that states do not want their universities to set maximum cutoff levels for in-state students. But as $s_{o}$ rises, $\Delta p_{o}\left(s_{o}\right) \tau_{o}\left(s_{o}\right)$ rises to a maximum and then falls sharply. At the point where $\Delta p_{o}\left(s_{o}\right) \tau_{o}\left(s_{o}\right)<\Delta p_{o}\left(s_{o}{ }^{\min }\right) \tau_{o}\left(s_{o}{ }^{\text {min }}\right)$, states want universities to set a maximum cutoff for out-of-state students. If the curve for in-state students also turned downward at high ability levels, then states might want universities to set maximum cutoff levels for in-state students as well. We test the model below.

These arguments suggest that states may have an interest in their public universities having an intermediate quality level: not too high because the highest ability students are unlikely to be influenced in their location decisions by whether they attend college in the state, but not too low because then relatively high ability in-state students would attend college elsewhere and be less likely to settle in the state as adults. ${ }^{6}$

\subsection{Summary}

The theory suggests several testable hypotheses. First, if universities' goal is to maximize average student ability and they are free to follow their own interests, then they are predicted to follow the "equal cutoff rule" or the "equal marginal revenue rule." Second, states prefer that universities follow the "equal additional tax payments rule" or the "tuition offset rule," under which

\footnotetext{
${ }^{6}$ Our model neglects various other reasons why states may favor admitting in-state students or high ability students to public universities, including peer effects (Rothschild and White, 1995) or state legislators' desire to appeal to voters who want their children to be admitted to the most selective public university.
} 
states gain equal additional revenue when a marginal out-of-state or in-state student is admitted to a public university. Third, states may have an interest in public universities' setting maximum as well as minimum cutoffs for in-state and/or out-of-state students, depending on how the highest ability students are influenced in their adult location decisions by attending the state university.

In testing these hypotheses, we use data for both public and private universities. This is because private universities are less likely to be influenced by their states' preferences, so that their behavior follows the model of university behavior just discussed. In contrast, public universities are likely to follow a path that is intermediate between their states' preferences and private universities' preferences.

\section{Empirical Work}

Our primary data source is the Mellon Foundation's College and Beyond $(C \& B)$. This dataset includes information from students at 27 selective to highly selective colleges and universities who entered college in 1976 or 1989 . The 1976 cohort includes 32,000 students and the 1989 cohort includes 36,000 students. $^{7}$ For both cohorts, we have information from college records. For the 1976 cohort, we also have information from a survey of graduates conducted in 1996 that asked questions concerning current state of residence and current income. There were 23,500 responses to the survey.

The $C \& B$ dataset fits our model well in that all of the institutions are selective and all enroll substantial numbers of both in-state and out-of-state students. But two drawbacks of the dataset are that the participating universities were not randomly selected (selection in part was based on willingness to participate) and only four public universities - University of Michigan, Ann Arbor; University of North Carolina, Chapel Hill; Miami University (Ohio); and Penn State University are included. The $C \& B$ private institutions are generally representative of selective private colleges and universities and the $C \& B$ public institutions are all flagship universities that compete regionally and nationally with private universities for academically talented students and enroll substantial numbers of out-of-state students. We address the question of whether the $C \& B$ sample is

\footnotetext{
${ }^{7}$ See Bowen and Bok (1998) for discussion of the $C \& B$ data. For the private institutions, all students in the entering class were included in the dataset. For the public universities, a sample of 2,000 students from each entering class was selected. We use institutional sample weights to account for the probability of being sampled. A list of institutions is in Appendix Table 1.
} 
representative of selective colleges/universities generally by repeating some of our calculations using a different dataset that covers more institutions (see below).

Table 1 shows that the average proportion of in-state students in the 1976 cohort was .83 at the public universities and .29 at the private universities, but in the 1989 cohort, these figures dropped to .76 and .23 , respectively. The increase in out-of-state students over the period reflects the increasing regional and national competition for students over the period.

\subsection{Do universities follow the "equal cutoff rule?"}

Turn first to the question of whether universities follow the "equal cutoff rule." We treat SAT scores as our measure of student ability. Because it is impossible to identify a single student as the marginal in-state or out-of-state student, we treat all in-state students in the lowest decile of the instate distribution at each university as marginal in-state students and we follow the same procedure for out-of-state students. However because athletes and minority students are heavily represented in the marginal group and they are likely to be admitted on different admissions criteria, we omit these students before constructing the sets of marginal in-state and out-of-state students. (If athletes and minorities were left in, we would primarily be testing institutions' cutoffs for these groups rather than for in-state versus out-of-state students. ${ }^{8}$ For each institution, we construct the average SAT score for in-state and out-of-state students in the lowest decile. We treat these values as the cutoffs, $\bar{s}_{i}$ and $\bar{s}_{o}$. We then compute the value of $\left(\bar{s}_{o}-\bar{s}_{i}\right)$ for each institution and we report $\left(\bar{s}_{o}-\bar{s}_{i}\right)$ averaged over the groups of public and private universities.

The results are given in the middle panel of table 1. For the 1976 cohort at public universities, the average value of $\left(\bar{s}_{o}-\bar{s}_{i}\right)$ is 51 points and the minimum and maximum values are 8 and 77 , respectively. The value of $\left(\bar{s}_{o}-\bar{s}_{i}\right)$ is significantly different from zero for three of the four institutions, using a one-tailed test. Thus our data suggest that public universities set higher minimum cutoff levels for out-of-state students. Now turn to private universities. The average value of $\left(\bar{s}_{o}-\bar{s}_{i}\right)$ is 10 points, with a minimum of -122 and a maximum of 81 . Thus, on average, private universities treat in-state and out-of-state students equally, but there is a wide range of

\footnotetext{
${ }^{8}$ Since no information was available concerning athletic scholarships, we defined athletes as anyone who played an intercollegiate sport during college. Minorities include African-Americans, Hispanics, and Native Americans. For public university students in the 1976 cohort, $40 \%$ of in-state students and $53 \%$ of out-of-state students in the lowest
} 
behavior. To gauge the importance of the admissions advantage given to in-state students, we calculate the share of the overall student distribution that is between the two cutoffs. For 1976, this figure is 5 percent at public universities, compared to less than 1 percent at private universities. Thus the in-state advantage at public universities is significant but not large, while in-state and outof-state students are treated equally at private universities. ${ }^{9}$

We repeat the analysis using the 1989 cohort and the results are shown on the right-hand side of table 1. The results show that public universities gave in-state students a larger advantage in 1989 than in $1976-84$ points versus 51, while private universities' behavior again treated both groups of students equally, but with wide variation in their behavior. Overall the results suggest that public universities consistently favor in-state students by a small margin, while private universities on average treat in-state and out-of-state students the same. ${ }^{10}$

In order to check on the representativeness of the $C \& B$ sample, we would like to replicate the analysis of the "equal cutoff rule" with a dataset that contains more institutions. However we found only one dataset that both contains more institutions and also has a large sample of students at each institution. The Higher Education Research Institute (HERI) at UCLA annually surveys college freshmen at a nationally representative sample of 4-year colleges and universities. Unfortunately HERI only began to collect data on students' state of residence starting in 2001, so that our replication is for a later time period.

We constructed two samples of institutions from the HERI data. The first includes 10 public and 39 private institutions that are as selective as those in the $C \& B$ dataset. The second adds 5 additional public and 46 additional private institutions, all taken from the next-most-selective category. All institutions in both samples have at least $10 \%$ out-of-state students. ${ }^{11}$ We followed the same procedure as above to calculate average values of $\left(\bar{s}_{o}-\bar{s}_{i}\right)$. The bottom panel of table 1 gives the results. Examine the more selective sample first. For the public universities, the average

decile were athletes or minorities. For private university students in the same cohort, the figures were $55 \%$ and $47 \%$, respectively. For the 1989 cohort, the figures were $44 \%, 58 \%, 69 \%$, and $57 \%$, respectively.

${ }^{9}$ For the private institutions in 1976, the value of $\left(\bar{s}_{o}-\bar{s}_{i}\right)$ is significantly different from zero for only 6 of 22 institutions, using a two-tailed test.

${ }^{10}$ The value of $\left(\bar{s}_{o}-\bar{s}_{i}\right)$ is significantly different from zero for all of the four public institutions in 1989, using a onetailed test. We also repeated the analysis using the lowest $20 \%$ of SAT scores, rather than the lowest $10 \%$, and the results were similar.

${ }^{11}$ All private institutions had at least an $85 \%$ participation rate by students in the HERI survey and all public institutions had a $75 \%$ participation rate. Institutions were also required to have data on students' home states and SAT/ACT scores for at least $75 \%$ of their students. There are 47,863 and 90,208 students in the two samples. See Sax et al. (2001) for a discussion of the HERI survey. 
value of $\left(\bar{s}_{o}-\bar{s}_{i}\right)$ is 49 points and the share of the overall distribution between the two cutoffs is 4

percent. For the 39 private institutions, the average value of $\left(\bar{s}_{o}-\bar{s}_{i}\right)$ is 33 points, but the range is large. The average share of the overall distribution between the cutoffs is 2 percent. Thus the results are similar to those using the $C \& B$, even though the time period is later. Now examine the results for the less selective sample. Both public and private institutions on average give a smaller preference to in-state students. For publics, the share of the overall distribution between the two cutoffs is only 3 percent, while for the privates, it is 1 percent. These results again suggest that selective public universities give in-state students a small advantage in admission, while private universities tend to treat students equally.

\subsection{Do universities follow the "equal marginal revenue rule"?}

In the theoretical discussion, we argued that universities follow the "equal marginal revenue rule," i.e., they set minimum cutoffs such that revenue from tuition plus donations is the same for marginal in-state versus marginal out-of-state students, or $D_{i}\left({\overline{s_{i}}}^{\prime}\right)+T_{i}=D_{o}\left(\bar{s}_{o}^{\prime}\right)+T_{o}$. The $C \& B$ dataset includes information concerning donations, but only for graduates of private institutions. It does not include information concerning individual student tuition levels (financial aid). We therefore ignore differences in tuition levels across in-state versus out-of-state students - which in any case are likely to be small for students at private institutions. The "equal marginal revenue rule" then simplifies to a rule of equal donations by marginal in-state versus out-of-state students, or $D_{i}\left(\bar{s}_{i}^{\prime}\right)=D_{o}\left(\bar{s}_{o}^{\prime}\right)$. Although we only have data for graduates of private universities, we analyze them on the grounds that the results are also suggestive for public universities' behavior, assuming that donations behavior by public versus private university graduates is similar. (Actually, most public universities did not regularly solicit donations from graduates as of the mid-1990's, but they appear to be moving in that direction.)

We have data on donations between 1991 and 1996 by graduates in the 1976 cohort. The data cover 18 of the private institutions in our dataset and are taken from the institutions' records. To determine $\left(D_{o}\left(\bar{s}_{o}^{\prime}\right)-D_{i}\left(\bar{s}_{i}^{\prime}\right)\right)$ for each institution, we constructed distributions of donations by the marginal groups of in-state and out-of-state students at each institution (again excluding athletes and minorities). We focus on the $75^{\text {th }}$ percentile value in each distribution, because average donations are heavily affected by large gifts and the median donation is usually zero. We found the 
difference between the $75^{\text {th }}$ percentile donation by marginal out-of-state versus marginal in-state students at each of the 18 institutions and then calculated the average value. The results are that the average value of $\left(D_{o}\left(\bar{s}_{o}^{\prime}\right)-D_{i}\left(\bar{s}_{i}^{\prime}\right)\right)$ is $\$ 17$ per year and the range is from $-\$ 58$ to $\$ 117$ per year. Out-of-state students give more than in-state students at 14 of the 18 institutions and the average difference in donations is $\$ 17$ per year. But the difference in donations is significantly different from zero at only one of the 14 institutions. Thus the results do not support the idea that universities give in-state students an advantage in admissions because they donate more. On the contrary, they suggest that private institutions, at least, have an interest in treating in-state and outof-state students equally. ${ }^{12}$

\subsection{The effect of attending college in a state on adult location choice.}

In order to test the "equal additional tax payments rule," we must estimate the increase in marginal in-state versus out-of-state students' probabilities of locating in a particular state as adults when they attend college there. These effects are denoted $\Delta p_{i}\left(\bar{s}_{i}\right)$ and $\Delta p_{o}\left(\bar{s}_{o}\right)$ for marginal instate and out-of-state students, respectively. Our sample consists of students in the 1976 cohort who responded to the 1996 survey, so that we observe students' locations 16 years after graduation from college. We drop students who are from outside the U.S. or lived outside the U.S. at the time of the survey. Also for reasons discussed below, we drop students if they did not answer survey questions that asked which universities they applied to.

We use a conditional logit model. Because students can locate in any of the 50 states plus the District of Columbia, each student enters the sample 51 times. ${ }^{13}$ The dependent variable equals one for the state where the student lived at the time of the survey and zero for all other states. Precollege and college locations are represented by three dummy variables: home equals one for the student's home state and zero otherwise, college equals one for the state in which the student attended college and zero otherwise, and home $\times$ college is an interaction between the home and college variables. ${ }^{14}$ The omitted category is states that are neither the student's home state nor his/her college state. We represent students' ability level with three dummy variables: low SAT

\footnotetext{
${ }^{12}$ The same result also emerges if we examine donation behavior only by students who donate positive amounts or if we run a regression explaining donations as a function of in-state versus out-of-state status, SAT score, and income at the time of the survey. The average donation in the marginal group of students is $\$ 66 /$ year.

${ }^{13}$ The conditional logit model is intended for situations in which individuals choose from among more than two mutually exclusive categories. See Greene (2000, Section 19.7).

${ }^{14}$ Students' home states are the states where the high schools from which they graduated are located.
} 
equals one if the student is in the lowest quintile of the SAT distribution for in-state or out-of-state students (whichever is relevant), middle SAT equals one if the student is in any of the three middle quintiles, and high SAT equals one if the student is in the highest quintile. Also we define a dummy variable for whether students attended public versus private universities. In order to estimate $\Delta p_{i}\left(\bar{s}_{i}\right)$ and $\Delta p_{o}\left(\bar{s}_{o}\right)$ for the marginal groups of students at public and private universities, we interact the three location variables with three SAT variables and interact the resulting variables with the public versus private variable. We also include state fixed effects. ${ }^{15}$

The results of the regression are given in Appendix table 2. The results are used to predict $p_{y y}$, $p_{y n}, \Delta p_{i}, p_{n y}, p_{n n}$, and $\Delta p_{o}$ for in-state versus out-of-state students in the lowest quintile of the SAT distribution at public and private universities. The results are shown in table 2, columns (1) and (2). Because state fixed effects are included in the regression, the estimates differ across states and we show the results for a representative state. ${ }^{16}$ The probability of marginal in-state students locating in their home states as adults if they attend college there $\left(p_{y y}\right)$ is .55 for public university students and .51 for private university students. These figures suggest that home state is an important factor in determining graduates' post-college location choices. If students instead attend college outside their home states, the probability of locating in their home states after college $\left(p_{y n}\right)$ falls to .32 for both public and private university students. ${ }^{17}$ Thus the increase in the probability of in-state students locating in their home states if they attend college there is $\Delta p_{i}\left(\bar{s}_{i}\right)=.55-.32=.23$ for public university students, compared to .19 for private university students. For marginal out-ofstate students, the probabilities of locating in the state where they attend college $\left(p_{n y}\right)$ are .15 and .07 if they attend public or private universities, respectively, and the probability of locating in a particular state if they are neither from the state nor attended college there $\left(p_{n n}\right)$ is .01 for both types of universities. Thus the increase in the probability that marginal out-of-state students locate

\footnotetext{
${ }^{15}$ We use the lowest quintile rather than the lowest decile of the relevant distributions as our marginal groups, because some of the data come from the post-college survey, which has fewer observations than the college records used in the previous section. State fixed effects are included to capture relative sizes of states, climate, and other factors that vary across states but not across individuals.

${ }^{16}$ We do not identify the representative state, because the confidentiality rules for the $C \& B$ dataset preclude reporting results for particular institutions and most states contain only one institution.

${ }^{17}$ This figure is calculated assuming that students from a particular state who attend an out-of-state institution rather than an in-state public university may attend either a public or a private institution. We make this assumption because the number of students in our sample who attended an out-of-state public university is fairly small. As a result, the value of $p_{y n}$ is the same for both public and private universities. A similar point applies to the calculations of $p_{n n}$.
} 
in a particular state if they attend college there $\left(\Delta p_{o}\left(\bar{s}_{o}\right)\right)$ is .14 for public university students and .06 for private university students.

An implication of these results is that attending a public university has a much larger effect on students' post-college location choices than attending a private university. This may be because, when students attend public universities, they meet many more in-state students than they would if they attended a private university in the same state. But another possibility, which we now consider, is that there may be selection bias arising from students' choice of where to attend college. In particular, whether students attend college in a particular state may be correlated with whether they would like to live in that state after graduation.

For example, students from Ohio who want to remain close to their families are likely both to attend college in Ohio and to locate in Ohio after graduation. But students from Ohio who want to live in warm climates are likely both to attend college in Arizona and to locate in Arizona (or another warm state) after graduation. Ignoring this factor causes our estimates to overstate the effect of going to college in a state on the probability of locating in that state after graduation. Our estimate of $p_{y y}$ is based on natives of a representative state who attend college in their home state. This group, on average, is predisposed to their home state as a post-college location. But our estimate of $p_{y n}$ is based on natives of the same state who go to college outside their home state and therefore tend to be predisposed against their home state as a post-college location. These effects cause our estimates of $p_{y y}$ to be biased upward and $p_{y n}$ to be biased downward, so that our estimate of $\Delta p_{i}$ is biased upward. Similarly, our estimate of $p_{n y}$ is based on non-natives of the representative state who attend college in the state and are predisposed to the state as a post-college location; while our estimate of $p_{n n}$ is based on non-natives of the state who don't attend college there and are pre-disposed against locating there. These effects cause our estimate of $\Delta p_{o}$ to be biased upward. In both cases, the treatment group is composed of students who are predisposed to the state and the control group is composed of students who are predisposed against the state.

To address this problem, we use information concerning the set of institutions that students applied to but did not attend. We have information on up to four such institutions. Since location preferences are a factor in college choice, students reveal information about their location preferences by the locations of the colleges they apply to. We re-estimate the model of adult location choice but with two changes. First, we restrict the sample to students who applied to 
colleges in more than one state, since this group of students does not have strong preferences to locate in a particular state. Second, we define a new dummy variable apply that equals one if a student applied to at least one institution in a state and zero otherwise. We interact apply with all of the variables involving home and we also introduce a new set of variables that interact apply with the dummy variables for the low, middle, and high SAT score regions and with the dummy variable for public versus private institution. Adding the latter group of variables allows us to use the information concerning students' applications to colleges in states other than their home or college states, where these states are the omitted category for the home and college variables. ${ }^{18}$

The results of the model are given in Appendix table 3. We use them to re-do our predictions of $p_{y y}, p_{y n}$, etc., for marginal students at public and private institutions, using the same representative state as before. The results are shown are in columns (3) and (4) of table 2. Comparing the adjusted and unadjusted results for public university students, we find that $p_{y y}$ falls from .55 to .45 and $p_{y n}$ rises from .32 to .34 . Both of these changes are in the predicted direction. This causes our estimate of $\Delta p_{i}\left(\bar{s}_{i}\right)$ for marginal in-state public university students to fall from .23 to .11. Similarly $p_{n y}$ falls from .15 to .14 and $p_{n n}$ rises from .01 to .04 , so that $\Delta p_{o}\left(\bar{s}_{o}\right)$ for marginal out-of-state public university students falls from .14 to .10. For private universities, the changes are similar: $\Delta p_{i}\left(\bar{s}_{i}\right)$ falls from .19 to .08 and $\Delta p_{o}\left(\bar{s}_{o}\right)$ falls from .06 to .02 . Thus adjusting for bias in the estimation of $\Delta p_{i}\left(\bar{s}_{i}\right)$ and $\Delta p_{o}\left(\bar{s}_{o}\right)$ sharply reduces the predicted effect of attending college in a state on the probability of graduates' locating in that state. For in-state students, the adjusted results show that attending a public university has only a slightly larger effect on post-college location choice than attending a private university does, although the difference remains large for out-of-state students. But the most surprising result of the adjustments is that attending a public university has nearly the same effect on whether marginal in-state versus out-ofstate students locate in the state after graduation (.11 versus .10). This differs from the unadjusted results, where the in-state student effect was considerably larger.

\subsection{Do universities follow the "equal additional tax payments rule?"}

\footnotetext{
${ }^{18} 40 \%$ of marginal in-state students and $80 \%$ of marginal out-of-state students applied to colleges in more than one state. There are no interactions between college and apply, since students must have applied to a college in the state
} 
Now consider the "equal additional tax payments rule," eq. (7). This says that states would like public and private universities within their boundaries to set cutoff levels such that the increase in expected future state tax payments when a marginal student is admitted is the same for students from in-state versus out-of-state. This requires that the difference between expected additional state tax payments from marginal in-state versus out-of-state students, $\Delta p_{i}\left(\bar{s}_{i}\right) \tau_{i}\left(\bar{s}_{i}\right)-\Delta p_{o}\left(\bar{s}_{o}\right) \tau_{o}\left(\bar{s}_{o}\right)$, equals zero. We refer to this term as Difference.

We estimated $\Delta p_{i}\left(\bar{s}_{i}\right)$ and $\Delta p_{o}\left(\bar{s}_{o}\right)$ in the previous section. Now turn to expected future state tax payments by marginal students, $\tau_{i}\left(\bar{s}_{i}\right)$ and $\tau_{o}\left(\bar{s}_{o}\right)$. Our only observation of graduates' incomes comes from their answers to the 1996 survey, which asked about income during the previous year. However, graduates earn income and pay taxes to the state every year. We therefore convert reported income in 1995 for each graduate in the sample into an estimate of lifetime income, expressed in 1995 dollars. We use age-earnings data for college graduates from Murphy and Welch (1990) and standard mortality tables. ${ }^{19}$ We estimate that lifetime income is 38 times the value of income in 1995. We then convert graduates' lifetime incomes into lifetime state tax payments by multiplying lifetime incomes by the sum of the income and sales tax rates in 1995 in the state where the graduate attended college. For all of the states represented in our sample, the average combined tax rate is 9.8 percent. $^{20}$

We then compute average lifetime state tax payments for in-state and out-of-state students in the lowest quintile of the relevant distribution for each institution in our sample. These are denoted $\tau_{i}\left(\bar{s}_{i}\right)$ and $\tau_{o}\left(\bar{s}_{o}\right)$, respectively. Because our estimates of average income are affected by students' location preferences, we compute $\tau_{i}\left(\bar{s}_{i}\right)$ and $\tau_{o}\left(\bar{s}_{o}\right)$ both with and without adjustments for location preferences. The unadjusted values of $\tau_{i}\left(\bar{s}_{i}\right)$ and $\tau_{o}\left(\bar{s}_{o}\right)$ are based on all students in the relevant

where they attended college. See Groen (2003) for further discussion of the specification and estimation results using a different dataset. The results are similar to those reported here.

${ }^{19}$ Murphy and Welch (1990, table 9) report that earnings of college graduates increase by $74.3 \%$ during the first 10 years of labor market experience, increase by $29.3 \%$ during the next 15 years of experience, and decline by $9.8 \%$ during the next 15 years of experience. Our figure for earned income is assumed to be for the $16^{\text {th }}$ year of labor market experience. We discount income over 10-year age ranges by the probability of death in that range, using mortality data for 1998 from Murphy (2000), table 23, p. 80. We do not apply a discount rate, since the figures for earnings growth are in real terms. The resulting figures underestimate true lifetime state tax payments because they neglect earnings from wealth and pensions, but they overestimate true lifetime state tax payments by assuming that all graduates work for 40 years and that all income is subject to taxes.

${ }^{20}$ See Council of State Governments (1996), tables 6.21 and 6.23. Tax rates are as of January 1, 1996. Note that most states' income taxes are approximately constant rather than strongly progressive. 
marginal group, while the adjusted values of $\tau_{i}\left(\bar{s}_{i}\right)$ and $\tau_{o}\left(\bar{s}_{o}\right)$ are based on students in the marginal group who applied to colleges in more than one state. ${ }^{21}$

The middle rows of table 3 report the results for $\tau_{i}\left(\bar{s}_{i}\right)$ and $\tau_{o}\left(\bar{s}_{o}\right)$, averaged over the groups of public versus private universities. The unadjusted estimates are shown in the left panel. At public universities, lifetime state tax payments by marginal out-of-state students are 25 percent higher than those by marginal in-state students $(\$ 225,000$ versus $\$ 177,000$, respectively). This difference could be due to strong location preferences by in-state students, who may pass up lucrative opportunities in order to remain near home. In addition, the difference could be explained by the lower average ability of marginal in-state students at public universities, since these students were subject to a lower minimum cutoff level for admission. Marginal private university students have higher lifetime state tax payments than marginal public university students, regardless of whether they are from in-state or out-of-state. This could reflect weaker preferences to remain near home or higher minimum cutoffs at private universities, or both. When the results are adjusted, as shown on the right side of table 3 , the differential between out-of-state versus in-state students at public universities falls ( $\$ 227,000$ versus $\$ 185,000$, respectively). But at private universities, the ranking is reversed and in-state students' average tax payments are higher than those of out-of-state students $(\$ 273,000$ versus $\$ 264,000$, respectively). Since we have adjusted for location preferences, the remaining differential probably reflects differences in average ability levels between out-of-state and in-state students.

Now turn to the value of Difference for the marginal group of students. The average unadjusted value for public universities is $\$ 9,400$ and the range for the various institutions in our sample is from $\$ 3,600$ to $\$ 16,800$. This reflects the balance of two opposing effects: in-state students earn less and therefore pay lower state taxes than out-of-state students, but the effect of attending university in the state on their adult location choices is higher. Since Difference is positive, the latter effect more than offsets the former. But with adjusted figures, the picture changes. The average adjusted value of Difference for public universities is $-\$ 2,000$, because instate students earn less than out-of-state students and the "pull" of attending university in the state is about the same. The implication is that, as of 1976, states would have benefited financially if public universities had reduced the advantage they gave to marginal in-state students and accepted more marginal out-of-state students.

${ }^{21}$ We again use the lowest $20 \%$ of in-state and out-of-state students (by SAT score) at each institution. 
For private universities, the results are different. The unadjusted average value of Difference for private universities is $\$ 32,600$ and the adjusted figure is $\$ 17,400$. Therefore state governments would collect more tax revenues if private universities had used lower minimum cutoff levels for in-state students in 1976.

\subsection{Test of the "tuition offset rule"}

Now consider the "tuition offset rule," eq. (8). Under this rule, the present value of extra state tax payments collected from a marginal in-state student rather than a marginal out-of-state student (Difference) should just offset the tuition differential between out-of-state and in-state students at public universities. To evaluate this rule, we need information for 1976 on the tuition differential between out-of-state and in-state students $\left(T_{o}-T_{i}\right)$ at each of the four public universities in the $C \& B$. We multiply the tuition differential by four years of college and then convert the result to 1995 dollars using the consumer price index. We adjust the tuition differential to take account of the fact that it is collected 16 to 19 years earlier than the date for which we calculate Difference, which is 1995 , using a real discount rate of .02 per year. The resulting average tuition differential is $\$ 25,600$.

Table 4 summarizes the tuition offset rule for the public universities in our sample, using both adjusted and unadjusted figures for state tax payments. Using the unadjusted figures, a marginal in-state student generates $\$ 9,400$ more in lifetime state tax payments than a marginal out-of-state student, but pays $\$ 25,600$ less in tuition, for a net loss to the state of $\$ 16,200$. Using the adjusted figures, the state's net loss is larger: $\$ 27,700$. These results suggest that states would have gained substantially if public universities had not favored in-state students as strongly as they did in 1976.

\subsection{Do states have an interest in setting maximum as well as minimum cutoffs?}

Now turn to whether states would gain if universities set maximum as well as minimum cutoff levels for in-state or out-of-state students. To investigate this issue, we calculate Difference separately for all three ability regions of the SAT distribution: the lowest quintile, the three middle quintiles, and the highest quintile. Instead of calculating Difference for each institution and then summarizing across groups of institutions (our procedure in the previous sections), we instead pool the individual-level data across institutions, keeping public versus private university students 
separate. For each group, we calculate average lifetime state tax payment. ${ }^{22}$ This procedure abstracts from the characteristics of existing institutions because we wish to address the general question of whether states gain when high ability students attend public or private universities within their borders. We use the same procedure to adjust for location preference as above.

Table 5 gives the results. For in-state students at public universities, the probabilities of locating in the home state after graduation $\left(p_{y y}\right)$ are $.45, .42$, and .39 for the lowest, middle, and highest ability groups, respectively. For out-of-state students, the probabilities of locating in the home state $\left(p_{y n}\right)$ are $.34, .28$, and .19 for the three groups, respectively. Thus home state becomes a smaller influence on adult location choice as ability increases, both for in-state and out-of-state students. This is probably because higher ability students have better opportunities generally than lower ability students, so that their best opportunities are more likely to involve leaving their home states. But a surprising result is that, because $p_{y n}$ falls faster than $p_{y y}, \Delta p_{i}\left(s_{i}\right)$ rises as ability increases: the figures are $.11, .13$, and .20 for the low, middle, and high ability groups, respectively. ${ }^{23}$ For in-state private university students, the highest value of $\Delta p_{i}\left(s_{i}\right)$ is again the value for high ability students: the figures are $.08, .06$, and .09 for the low, middle and high ability groups, respectively. Thus high ability students are more influenced in their adult location choices by attending college in their home states than are middle or low ability students, regardless of whether they attend public or private universities.

Now consider out-of-state students. For public universities, $p_{n y}$ and $p_{n n}$ are not monotonically related to ability and therefore $\Delta p_{o}\left(s_{o}\right)$ does not have a consistent pattern: it is .10, .09 , and .11 for the low, middle, and high ability groups, respectively. At private universities, $\Delta p_{o}\left(s_{o}\right)$ is lower and again does not have a monotonic relationship with ability: it is $.02, .04$, and .03 for the low, middle, and high ability groups, respectively. Thus there is little relationship between ability and how out-of-state students' location choices are influenced by where they attend college. The only strong pattern for out-of-state students is that their adult location choices are more strongly influenced by where they attend college if they attend a public rather than private institution.

\footnotetext{
${ }^{22}$ In the calculations, we use only students who applied to colleges in more than one state. The SAT score ranges for the three groups of students are: 400-1040, 1040-1330, and 1330-1600.

${ }^{23}$ The difference between the figures for the low versus high ability groups is statistically significant (see table 5).
} 
Now turn to the lifetime state tax payment figures in table 5. As expected, they increase monotonically with ability for all types of students. For example, in-state public university students have lifetime state tax payments of \$205,000, \$237,000, and \$292,000 in the lowest, middle, and highest SAT categories, respectively. The increases are similar for other groups of students. Also within ability levels, out-of-state students have higher lifetime state tax payments than in-state students at public universities, but the pattern is reversed at private universities. (However, the differences are usually not statistically significant.)

The figures for Difference, $\Delta p_{i}\left(\bar{s}_{i}\right) \tau_{i}\left(\bar{s}_{i}\right)-\Delta p_{o}\left(\bar{s}_{o}\right) \tau_{o}\left(\bar{s}_{o}\right)$, are given at the bottom of Table 5 . Because both the "pull" of attending college in a particular state and lifetime state tax payments increase with ability, Difference also increases with ability. For public university students, the figures are $-\$ 700, \$ 5,100$, and $\$ 22,900$ for the lowest, middle, and highest ability groups, respectively, and for private university students, they are $\$ 16,800, \$ 8,000$, and $\$ 20,600$. Because Difference is negative only for low ability public university students, the results suggest that states lose financially when public universities admit additional in-state students from the lowest ability group and gain financially when they admit additional in-state students from either the middle or the highest ability groups.

Putting these results together, they suggest the following: (1) States would gain financially if public universities reduced the extent to which they favor in-state over out-of-state students at the low ability margin. (2) States would also gain financially if public universities attracted more high ability students, both from in-state and out-of-state. This is because high ability students tend to be more influenced in their adult location decisions by where they attend college than are middle or low ability in-state students and they also pay the highest state taxes. This suggests a rationale for public support of at least one flagship public university that has high academic quality and is likely to attract high ability students from both in-state and out-of-state. (3) States also have a large financial gain when private universities within their boundaries attract high ability in-state students, although the gain is lower when private universities attract high ability out-of-state students. This suggests a rationale for states to subsidize scholarships for high-ability in-state students at private universities within their boundaries. (4) Finally, our data do not support the idea of imposing maximum cutoff levels at public universities for either in-state or out-of-state students. This is because states gain more financially when an additional high ability student is admitted than when 
an additional low ability student from in-state is admitted, regardless of whether the high ability student is from in-state or out-of-state.

\section{Conclusions}

In this paper, we examine the divergence of interest between universities and state governments concerning standards for admitting in-state versus out-of-state students. States have an interest in using universities to attract and retain high ability individuals because they pay higher state taxes and contribute more to economic development. In contrast, universities have an interest in their graduates being successful, but little interest in where their students come from or where they go after graduation. We show that universities have an incentive to set equal admissions cutoffs for marginal in-state versus out-of-state students. In contrast, states may gain when universities set lower minimum admissions cutoffs for in-state than out-of-state students, if in-state students' future location choices are more affected by attending public university than are out-of-state students'.

We test the predictions of the model for both public and private universities, using the Mellon Foundation's College \& Beyond dataset. Because the $C \& B$ dataset covers only a limited number of universities that were not randomly selected, our results are more tentative than they would be with a larger and more representative set of institutions.

We find that when athletes and minorities are omitted from the analysis, public universities consistently set lower minimum admissions cutoffs for in-state than out-of-state students. The proportion of students who are between the in-state and out-of-state minimum cutoffs is 5 to 8 percent. Private universities, in contrast, treat in-state and out-of-state applicants equally. Surprisingly, we find that states gain more in expected future state tax revenues when marginal out-of-state students are admitted to public universities than when marginal in-state students are admitted. Thus when states pressure their public universities to set lower cutoffs for in-state than out-of-state applicants, they are acting against their own financial interest.

We also investigate whether states would gain if public universities set maximum as well as minimum cutoffs for admission of in-state or out-of-state students, i.e., if they discouraged high ability students from attending. We find that as ability increases, students are more rather than less influenced in their location decisions by where they attend college, regardless of whether they are from in-state or out-of-state. And because higher ability students pay higher state taxes, states benefit when higher ability students from both in-state and out-of-state attend public universities. 
Thus states would not benefit from public universities setting maximum cutoffs for admission. On the contrary, they gain from having a flagship university that attracts high ability students from both in-state and out-of-state. 


\section{References}

Bowen, W.G. and D. Bok (1998), The Shape of the River: Long-Term Consequences of Considering Race in College and University Admissions. Princeton, N.J.: Princeton Univ. Press.

Council of State Governments (1996), The Book of the States, 1996-97 edition (vol. 31). Lexington, KY.

Dale, S.B., and A.B. Krueger (2002), "Estimating the Payoff to Attending a More Selective College: An Application of Selection on Observables and Unobservables," Quarterly Journal of Economics, vol. 117, pp. 1491-1528.

Epple, D., R. Romano, and H. Sieg (1999), "Peer Effects, Financial Aid, and Selection of Students into Colleges and Universities: An Empirical Analysis," working paper, Carnegie Mellon Univ. Forthcoming, Journal of Applied Econometrics.

Fan, W., and M.J. White (2002), "Personal Bankruptcy and the Level of Entrepreneurial Activity." NBER working paper no. 9340. Forthcoming, J. of Law \& Economics.

Goldin, C., and L. Katz (1998), "The Origins of State-Level Differences in the Public Provision of Higher Education: 1890-1940," American Economic Review, vol. 88, pp. 303-308.

Greene, W.H. (2000), Econometric Analysis, $4^{\text {th }}$ edition. New Jersey: Prentice-Hall.

Groen, J. (2003), “The Effect of College Location on Migration of College-Educated Labor," working paper, Cornell University.

Hoxby, C.M. (1997), "How the Changing Market Structure of U.S. Higher Education Explains College Tuition," NBER working paper no. 6323.

Mixon, F.G., Jr., and Y. Hsing (1994), "The Determinants of Out-of-State Enrollments in Higher Education: A Tobit Analysis," Economics of Education Review, vol. 13, pp. 329-35.

Moretti, E. (2002), "Estimating the Social Return to Higher Education: Evidence from Longitudinal and Repeated Cross-Sectional Data," NBER working paper no. 9108. Forthcoming, Journal of Econometrics.

Murphy, K.M., and F. Welch (1990), “Empirical Age-Earnings Profiles," Journal of Labor Economics, vol. 8, pp. 202-229.

Murphy, S.L. (2000), “Deaths: Final Data for 1998," National Vital Statistics Reports, Vol. 48, No. 11. Hyattsville, Md.: National Center for Health Statistics.

Quigley, J.M., and D.L. Rubinfeld (1993), "Public Choices in Public Higher Education," in Clotfelter, C.T. and M. Rothschild, eds., Studies of Supply and Demand in Higher Education. Chicago: Univ. of Chicago Press, pp. 243-278.

Rothschild, M., and L.J. White (1995), "The Analytics of the Pricing of Higher Education and Other Services in Which the Customers are Inputs," Journal of Political Economy, vol. 103, pp. 573-586.

Sax, L.J., J.A. Lindholm, A.W. Astin, W.S. Korn, and K.M. Mahoney (2001), The American Freshman: National Norms for Fall 2001. Los Angeles: Higher Education Research Institute, UCLA. 
Strathman, J. (1994), "Migration, Benefit Spillovers and State Support of Higher Education," Urban Studies, vol. 31, pp. 913-920. 
Figure 1:

Student Ability and Future State Tax Payments by In-State vs. Out-of-State Students:

An Example

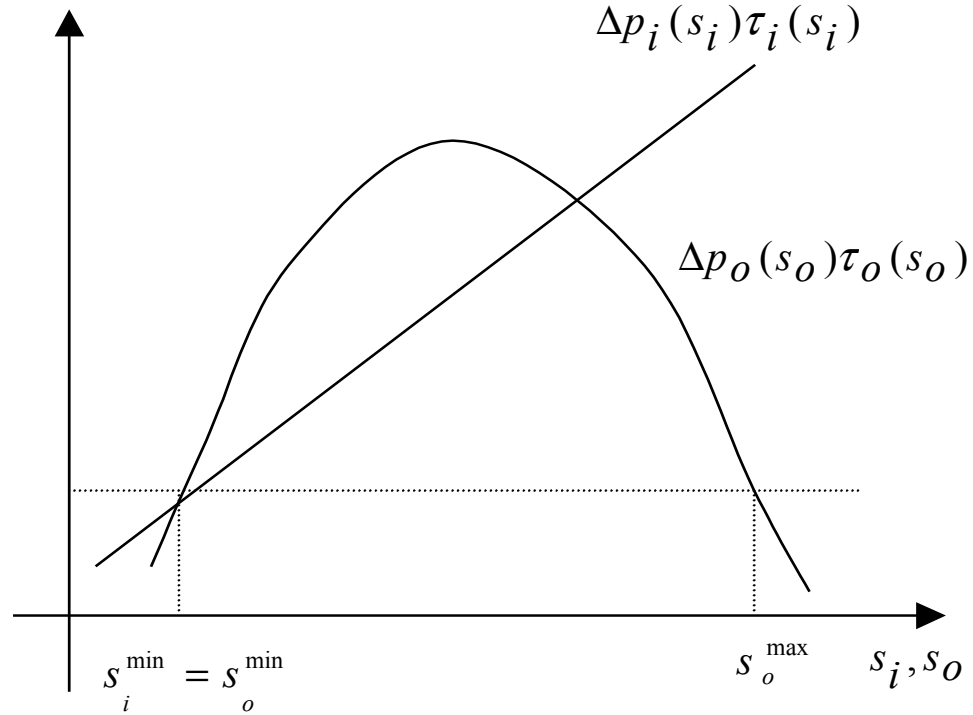


Table 1:

Tests of the Equal Cutoff Rule

Using the Lowest Decile of Students

All students

\begin{tabular}{l|cccc}
\hline & \multicolumn{3}{|c}{ 1976 cohort } & \multicolumn{2}{c}{ 1989 cohort } \\
& Public & Private & Public & Private \\
Number of institutions & 4 & 23 & 4 & 23 \\
Proportion in-state & .83 & .29 & .76 & .23 \\
\hline
\end{tabular}

Non-athletes and non-minorities

\begin{tabular}{l|cccc}
\hline$\left(\bar{s}_{o}-\bar{s}_{i}\right)$ (mean) & 51 & 10 & 84 & 36 \\
$\left(\bar{s}_{o}-\bar{s}_{i}\right)$ (min, max) & 8,77 & $-122,81$ & 33,117 & $-66,137$ \\
Share between & .05 & .00 & .08 & .01 \\
$\bar{s}_{i}$ and $\bar{s}_{o}$ (mean) & & & & \\
\hline
\end{tabular}

Results using HERI data (2001 cohort)

\begin{tabular}{l|cccc}
\hline & \multicolumn{2}{|c}{ More selective sample } & \multicolumn{2}{c}{ Less selective sample } \\
$\left(\bar{s}_{o}-\bar{s}_{i}\right)$ (mean) & 49 & 33 & 38 & 23 \\
$\left(\bar{s}_{o}-\bar{s}_{i}\right)$ (min, max) & 12,98 & $-46,128$ & $-15,98$ & $-89,128$ \\
Share between & .04 & .02 & .03 & .01 \\
$\bar{s}_{i}$ and $\bar{S}_{o}$ (mean) & & & & \\
\hline
\end{tabular}


Table 2:

Effect of Attending College in a State on the Probability of Locating in the State after College Students in the Lowest SAT Quintile

\begin{tabular}{|l|l|l|l|l|l|}
\hline & \multicolumn{2}{|c|}{ Not adjusted for selection bias: } & & \multicolumn{2}{c|}{ Adjusted for selection bias: } \\
\hline & \multicolumn{1}{|c|}{$(1)$} & \multicolumn{1}{|c|}{$(2)$} & & \multicolumn{1}{c|}{$(3)$} & \multicolumn{1}{c|}{$(4)$} \\
\hline & \multicolumn{1}{|c|}{ Public } & \multicolumn{1}{|c|}{ Private } & & \multicolumn{1}{c|}{ Public } & Private \\
\hline$\Delta p_{i}\left(\bar{s}_{i}\right)$ & $0.226(0.005)$ & $0.189(0.007)$ & $\Delta p_{i}\left(\bar{s}_{i}\right)$ & $0.114(0.008)$ & $0.082(0.011)$ \\
\hline$p_{y y}$ & 0.55 & 0.51 & $p_{y y}$ & 0.45 & 0.42 \\
\hline$p_{y n}$ & 0.32 & 0.32 & $p_{y n}$ & 0.34 & 0.34 \\
\hline$\Delta p_{o}\left(\bar{s}_{o}\right)$ & $0.136(0.011)$ & $0.057(0.003)$ & $\Delta p_{o}\left(\bar{s}_{o}\right)$ & $0.102(0.011)$ & $0.019(0.002)$ \\
\hline$p_{n y}$ & 0.15 & 0.07 & $p_{n y}$ & 0.14 & 0.06 \\
\hline$p_{n n}$ & 0.01 & 0.01 & $p_{n n}$ & 0.04 & 0.04 \\
\hline
\end{tabular}

Notes: $p_{y y}$ is the probability of students locating in their home states as adults if they attend college there, $p_{y n}$ is the probability of students locating in their home states as adults if they attend college out-of-state, and $\Delta p_{i}=p_{y y}-p_{y n}$ is the increase in the probability of in-state students locating in their home states if they attend college there rather than elsewhere. $p_{n y}, p_{n n}$, and $\Delta p_{o}$ are analogously defined for students who attend college outof-state. All values are for students in the lowest quintile of SAT scores and are for a representative state. Standard errors are in parentheses. 
Table 3:

Tests of the "Equal Additional Tax Payments Rule"

\begin{tabular}{|l|c|c|c|c|}
\hline & \multicolumn{2}{|c|}{ Unadjusted } & \multicolumn{2}{c|}{ Adjusted } \\
\hline & Public & Private & Public & Private \\
\hline$\Delta p_{i}\left(\bar{s}_{i}\right)$ & 0.226 & 0.189 & 0.114 & 0.082 \\
\hline$\Delta p_{o}\left(\bar{s}_{o}\right)$ & 0.136 & 0.057 & 0.102 & 0.019 \\
\hline & & & & \\
\hline$\tau_{i}\left(\bar{s}_{i}\right)$ (mean) & $\$ 177,100$ & $\$ 254,500$ & $\$ 185,300$ & $\$ 273,300$ \\
\hline$\tau_{o}\left(\bar{s}_{o}\right)$ (mean) & $\$ 225,400$ & $\$ 272,300$ & $\$ 227,100$ & $\$ 264,400$ \\
\hline & & & & \\
\hline Difference (mean) & $\$ 9,400$ & $\$ 32,600$ & $-\$ 2,000$ & $\$ 17,400$ \\
\hline Difference (min, max) & $\$ 3,600, \$ 16,800$ & $\$ 11,000, \$ 59,000$ & $-\$ 8,600, \$ 4,900$ & $\$ 6,100, \$ 39,000$ \\
\hline
\end{tabular}

Table 4:

Test of the "Tuition Offset Rule" at Public Universities

\begin{tabular}{lcc}
\hline & Unadjusted & Adjusted \\
\hline $\begin{array}{l}\text { Mean value of the difference in lifetime } \\
\text { expected state tax payments between in- } \\
\text { state versus out-of-state students, in } 1995\end{array}$ & $\$ 9,400$ & $-\$ 2,000$ \\
dollars (Difference): & & \\
& & \\
$\begin{array}{l}\text { Mean value of the four year tuition } \\
\text { differential for in-state versus out-of-state } \\
\text { students, in 1995 dollars: }\end{array}$ & $-\$ 25,600$ & $-\$ 25,600$ \\
$\begin{array}{l}\text { Net Amount: } \\
\quad \text { (mean) } \\
\text { (min, max) }\end{array}$ & & \\
\hline
\end{tabular}


Table 5:

Do States Gain When High and Middle Ability Students Attend College in the State?

\begin{tabular}{|c|c|c|c|c|c|c|}
\hline & \multicolumn{3}{|c|}{ Public } & \multicolumn{3}{|c|}{ Private } \\
\hline SAT category & Low & Middle & High & Low & Middle & High \\
\hline$p_{y y}$ & .45 & .42 & .39 & .42 & .34 & .28 \\
\hline$p_{y n}$ & .34 & .28 & .19 & .34 & .28 & .19 \\
\hline$\Delta p_{i}\left(s_{i}\right)$ & $.114(.008)$ & $.131(.009)$ & $.198(.022)$ & $.082(.011)$ & $.060(.011)$ & $.091(.005)$ \\
\hline$p_{n y}$ & .14 & .13 & .15 & .06 & .07 & .07 \\
\hline$p_{n n}$ & .04 & .03 & .04 & .04 & .03 & .04 \\
\hline$\Delta p_{o}\left(s_{o}\right)$ & $.102(.011)$ & $.094(.006)$ & $.114(.023)$ & $.019(.002)$ & $.037(.003)$ & $.034(.001)$ \\
\hline$\tau_{i}\left(s_{i}\right)$ & $\begin{array}{c}\$ 205,100 \\
(9,000)\end{array}$ & $\begin{array}{c}\$ 236,700 \\
(8,000)\end{array}$ & $\begin{array}{c}\$ 291,900 \\
(22,900)\end{array}$ & $\begin{array}{c}\$ 262,100 \\
(17,800)\end{array}$ & $\begin{array}{c}\$ 309,600 \\
(8,700)\end{array}$ & $\begin{array}{c}\$ 347,900 \\
(14,000)\end{array}$ \\
\hline$\tau_{o}\left(s_{o}\right)$ & $\begin{array}{c}\$ 236,600 \\
(16,900)\end{array}$ & $\begin{array}{c}\$ 275,600 \\
(13,000)\end{array}$ & $\begin{array}{c}\$ 305,900 \\
(29,100)\end{array}$ & $\begin{array}{c}\$ 248,800 \\
(8,500)\end{array}$ & $\begin{array}{c}\$ 286,500 \\
(3,800)\end{array}$ & $\begin{array}{c}\$ 326,400 \\
(6,300)\end{array}$ \\
\hline$\Delta p_{i}\left(s_{i}\right) \tau_{i}\left(s_{i}\right)$ & $\$ 23,400$ & $\$ 31,000$ & $\$ 57,800$ & $\$ 21,500$ & $\$ 19,000$ & $\$ 31,700$ \\
\hline$\Delta p_{o}\left(s_{o}\right) \tau_{o}\left(s_{o}\right)$ & $\$ 24,100$ & $\$ 25,900$ & $\$ 34,900$ & $\$ 4,700$ & $\$ 10,600$ & $\$ 11,100$ \\
\hline Difference & $-\$ 700$ & $\$ 5,100$ & $\$ 22,900$ & $\$ 16,800$ & $\$ 8,000$ & $\$ 20,600$ \\
\hline
\end{tabular}

Notes: All figures are adjusted for location preferences. Standard errors are in parentheses. 


\section{Appendix Table 1: \\ Institutions in the College and Beyond Dataset Used in Our Study}

\section{Public Institutions}

Miami University (Ohio)

University of Michigan (Ann Arbor)

University of North Carolina (Chapel Hill)

Pennsylvania State University

\section{Private Institutions}

$\begin{array}{ll}\text { Universities } & \text { Colleges } \\ \text { Columbia University } & \text { Barnard College } \\ \text { Duke University } & \text { Bryn Mawr College } \\ \text { Emory University } & \text { Denison University } \\ \text { Georgetown University } & \text { Hamilton College } \\ \text { Northwestern University } & \text { Kenyon College } \\ \text { University of Notre Dame } & \text { Oberlin College } \\ \text { University of Pennsylvania } & \text { Smith College } \\ \text { Princeton University } & \text { Swarthmore College } \\ \text { Rice University } & \text { Wellesley College } \\ \text { Stanford University } & \text { Wesleyan College } \\ \text { Tufts University } & \text { Williams College } \\ \text { Tulane University } & \\ \text { Vanderbilt University } & \\ \text { Washington University } & \\ \text { Yale University } & \end{array}$




\section{Appendix Table 2: \\ Conditional Logit Model Estimates \\ Without Controls for Initial Location Preferences}

\begin{tabular}{lrr}
\hline \multicolumn{1}{c}{ Variable } & Coefficient & Std. Error \\
\hline Home & 2.804 & 0.029 \\
home $\times\{$ SAT low $\} \times$ public & -0.067 & 0.151 \\
home $\times\{$ SAT low $\} \times$ private & 0.338 & 0.068 \\
home $\times\{$ SAT middle $\} \times$ public & -0.119 & 0.110 \\
home $\times\{$ SAT high $\} \times$ public & -0.617 & 0.251 \\
home $\times\{$ SAT high $\} \times$ private & -0.399 & 0.055 \\
College & & \\
college $\times\{$ SAT low $\} \times$ public & 1.630 & 0.044 \\
college $\times\{$ SAT low $\} \times$ private & 0.701 & 0.191 \\
college $\times\{$ SAT middle $\} \times$ public & 0.024 & 0.116 \\
college $\times\{$ SAT high $\} \times$ public & 0.532 & 0.150 \\
college $\times\{$ SAT high $\} \times$ private & 0.455 & 0.301 \\
& -0.159 & 0.078 \\
home $\times$ college & & \\
home $\times$ college $\times\{$ SAT low $\} \times$ public & -1.185 & 0.071 \\
home $\times$ college $\times\{$ SAT low $\} \times$ private & 0.001 & 0.281 \\
home $\times$ college $\times\{$ SAT middle $\} \times$ public & 0.124 & 0.178 \\
home $\times$ college $\times\{$ SAT high $\} \times$ public & 0.010 & 0.214 \\
home $\times$ college $\times\{$ SAT high $\} \times$ private & 0.329 & 0.449 \\
State fixed effects & 0.244 & 0.136 \\
Log - ikelihood & & \\
Pseudo $\mathrm{R}^{2}$ & Yes & \\
\hline
\end{tabular}

Notes: home is an indicator for students being from the state and college is an indicator for students attending college in the state. \{SAT low $\},\{$ SAT middle\}, and $\{$ SAT high indicate SAT scores in the lowest quintile, the middle three quintiles, and the highest quintile, respectively, of the distribution of SAT scores. \{public\} and \{private\} indicate that the student attended a public or private university/college. The sample size is 19,113 . 


\section{Appendix Table 3: \\ Conditional Logit Model Estimates \\ With Controls for Initial Location Preferences}

\begin{tabular}{|c|c|c|}
\hline Variable & Coefficient & Std. Error \\
\hline home & 2.723 & 0.035 \\
\hline home $\times$ apply $\times\{$ SAT low $\} \times$ public & -1.166 & 0.266 \\
\hline home $\times$ apply $\times\{$ SAT low $\} \times$ private & -0.476 & 0.139 \\
\hline home $\times$ apply $\times\{$ SAT middle $\} \times$ public & -0.988 & 0.188 \\
\hline home $\times$ apply $\times\{$ SAT middle $\} \times$ private & -0.671 & 0.072 \\
\hline home $\times$ apply $\times\{$ SAT high $\} \times$ public & -1.857 & 0.478 \\
\hline home $\times$ apply $\times\{$ SAT high $\} \times$ private & -1.149 & 0.103 \\
\hline College & 0.954 & 0.245 \\
\hline college $\times\{$ SAT low $\} \times$ private & -0.470 & 0.291 \\
\hline college $\times\{$ SAT middle $\} \times$ public & 0.141 & 0.307 \\
\hline college $\times\{$ SAT middle $\} \times$ private & -0.189 & 0.253 \\
\hline college $\times\{$ SAT high $\} \times$ public & 0.327 & 0.464 \\
\hline college $\times\{$ SAT high $\} \times$ private & -0.309 & 0.262 \\
\hline home $\times$ college & -0.375 & 0.378 \\
\hline home $\times$ college $\times\{$ SAT low $\} \times$ private & 0.074 & 0.443 \\
\hline home $\times$ college $\times\{$ SAT middle $\} \times$ public & -0.198 & 0.467 \\
\hline home $\times$ college $\times\{$ SAT middle $\} \times$ private & -0.192 & 0.391 \\
\hline home $\times$ college $\times\{$ SAT high $\} \times$ public & 0.654 & 0.744 \\
\hline home $\times$ college $\times\{$ SAT high $\} \times$ private & 0.109 & 0.409 \\
\hline Apply & 1.526 & 0.150 \\
\hline apply $\times\{$ SAT low $\} \times$ private & -0.443 & 0.183 \\
\hline apply $\times\{$ SAT middle $\} \times$ public & -0.276 & 0.189 \\
\hline apply $\times\{$ SAT middle $\} \times$ private & -0.571 & 0.157 \\
\hline apply $\times\{$ SAT high $\} \times$ public & -0.596 & 0.285 \\
\hline apply $\times\{$ SAT high $\} \times$ private & -0.550 & 0.165 \\
\hline State fixed effects & Yes & \\
\hline Log-Likelihood & $-34,087$ & \\
\hline Pseudo $\mathrm{R}^{2}$ & 0.3217 & \\
\hline
\end{tabular}

Notes: home is an indicator for students being from the state and college is an indicator for students attending college in the state. apply is an indicator for students applying to a college in the state. \{SAT low, , \{SAT middle\}, and \{SAT high\} indicate SAT scores in the lowest quintile, any of the middle three quintiles, and the highest quintile, respectively. \{public\} and \{private\} indicate that the student attended a public or private university. The sample size, 12,781, is smaller than in Appendix Table 2 because only students that applied to institutions in more than one state are included. 


\section{Appendix Table 4 \\ Institutions in the HERI Dataset Used in Our Study}

\section{First Sample}

\section{Public Universities}

Georgia Institute of Technology

Iowa State University

Miami University (Ohio)

University of Massachusetts (Amherst)

University of Michigan (Ann Arbor)

University of Minnesota (Twin Cities)

University of Pittsburgh

University of Vermont

University of Virginia

Virginia Polytechnic Institute and State U

\section{Private Universities}

Carnegie Mellon University

Duke University

Emory University

Johns Hopkins University

Northwestern University

Rice University

Stanford University

University of Rochester

Vanderbilt University

\author{
Private Colleges \\ Babson College \\ Bard College \\ Barnard College \\ Bates College \\ Beloit College \\ Bowdoin College \\ Bryn Mawr College \\ Bucknell University \\ Carleton College \\ Claremont McKenna College \\ Colby College \\ Connecticut College \\ Grinnell College \\ Harvey Mudd College \\ Haverford College \\ Macalester College \\ Middlebury College \\ Reed College \\ Rose-Hulman Institute of Technology \\ Scripps College \\ Stevens Institute of Technology \\ Trinity College \\ University of Richmond \\ Washington and Lee University \\ Wellesley College \\ Wesleyan University \\ Wheaton College \\ Whitman College \\ Williams College \\ Worcester Polytechnic Institute
}

\section{Additional Institutions in the Second Sample}

\section{Public Universities}

Ohio State University

Purdue University (Indiana)

University of Alabama

University of Arkansas (Fayetteville)

Utah State University
Private Universities

Boston College

Clarkson University

Cornell University

New York University

Rensselaer Polytechnic Institute

Santa Clara University

Tulane University

University of San Diego

University of Southern California

Villanova University

Wake Forest University
Private Colleges

Allegheny College
Bentley College
Berry College
Bethany College
Centre College
Chapman University
Clark University
Coe College
Elizabethtown College
Furman University
Gettysburg College


Goucher College

Hamilton College

Hiram College

Hobart and William Smith Colleges

Hollins University

Illinois Wesleyan University

John Brown University

Juniata College

Kettering University

Knox College

Lafayette College

Milwaukee School of Engineering

Oklahoma Christian University

Pacific University

Pepperdine University

Pitzer College

Rochester Institute of Technology

Rollins College

Saint Lawrence University

Siena College

Ursinus College

Wabash College

Willamette University 